\title{
Absence of superoxide dismutase activity causes nuclear DNA fragmentation during the aging process
}

\author{
Khandaker Ashfaqul Muid, Hüseyin Çaglar Karakaya, Ahmet Koc* \\ Izmir Institute of Technology, Department of Molecular Biology \& Genetics, 35430 Urla, Izmir, Turkey
}

\section{A R T I C L E I N F O}

\section{Article history:}

Received 8 January 2014

Available online 22 January 2014

\section{Keywords:}

Oxidative stress

Antioxidant

SOD

Superoxide dismutase

Aging

Longevity

DNA damage

Comet assay

ROS

Reactive oxygen species

\begin{abstract}
A B S T R A C T
Superoxide dismutases (SOD) serve as an important antioxidant defense mechanism in aerobic organisms, and deletion of these genes shortens the replicative life span in the budding yeast Saccharomyces cerevisiae. Even though involvement of superoxide dismutase enzymes in ROS scavenging and the aging process has been studied extensively in different organisms, analyses of DNA damages has not been performed for replicatively old superoxide dismutase deficient cells. In this study, we investigated the roles of SOD1, SOD2 and CCS1 genes in preserving genomic integrity in replicatively old yeast cells using the single cell comet assay. We observed that extend of DNA damage was not significantly different among the young cells of wild type, sod $1 \Delta$ and $\operatorname{sod} 2 \Delta$ strains. However, ccs $1 \Delta$ mutants showed a $60 \%$ higher amount of DNA damage in the young stage compared to that of the wild type cells. The aging process increased the DNA damage rates 3 -fold in the wild type and more than 5 -fold in $\operatorname{sod} 1 \Delta, \operatorname{sod} 2 \Delta$, and $\operatorname{ccs} 1 \Delta$ mutant cells. Furthermore, ROS levels of these strains showed a similar pattern to their DNA damage contents. Thus, our results confirm that cells accumulate DNA damages during the aging process and reveal that superoxide dismutase enzymes play a substantial role in preserving the genomic integrity in this process.
\end{abstract}

(c) 2014 Elsevier Inc. All rights reserved.

\section{Introduction}

Aging may be defined as a multi factorial phenomenon characterized by a time dependent decline in physiological function [1]. The mechanisms of aging, while not fully understood, is clearly associated with an increase in levels of molecular damage over the time, which contributes to increasing pathology and mortality at the organismal level $[2,3]$.

The budding yeast Saccharomyces cerevisiae is one of the most important model organisms used in aging-related research. Studies have demonstrated that replicative senescence of yeast cells involves a collapse of the antioxidant defense mechanisms and accumulation of oxidative damage to cellular components [4]. DNA integrity and stability of an organism is fundamental for survival, even under the best circumstances DNA is continuously damaged by endogenous or exogenous genotoxic agents $[5,6]$.

It is estimated that about $1-2 \%$ of the total oxygen consumed by mitochondria is transformed into 02 [7]. SOD enzymes catalyze the dismutation of superoxide into oxygen and hydrogen peroxide and they form an important antioxidant defense in nearly all cells exposed to oxygen [8]. SOD enzymes generally present in two forms inside a eukaryotic cell, $\mathrm{Cu} / \mathrm{ZnSOD}$ (Sod1) resides in the cytoplasm and the inner membrane space of mitochondria and MnSOD (Sod2)

\footnotetext{
* Corresponding author. Fax: +90 2327507303.

E-mail address: ahmetkoc@iyte.edu.tr (A. Koc).
}

mainly present in the mitochondrial matrix [9]. Copper chaperone Ccs1 is involved in the oxidative stress protection and has been characterized in S. cerevisiae [10]. It functions as a copper transporter for Sod1 [11]. Although Ccs1 share a significant sequence homology with Sod1, it has no superoxide dismutase activity. However, the D200H point mutation converts Ccs1 into a superoxide dismutase [12].

In this study, we optimized the yeast comet assay to study the roles of superoxide dismutases in preserving genomic integrity during the aging process. We observed that young cells lacking SOD1 and SOD2 genes have normal levels of ROS and DNA damage; however, cells without CCS1 gene had a significant increase in both ROS production and DNA damage rates. Furthermore, the aging process is a significant factor that increases these rates, and absence of SOD1, SOD2 and CCS1 genes further exaggerate them.

\section{Materials and methods}

\subsection{Yeast strains, culture and sample preparation}

Wild type (WT) strain BY4741 (MATa his $3 \Delta 1$ leu2 $\Delta 0$ met $15 \Delta 0$ $\operatorname{ura3} \Delta 0)$ and its isogenic mutants $(\operatorname{sod} 1 \Delta, \operatorname{sod} 2 \Delta$ and $\operatorname{ccs} 1 \Delta)$ were used in the experiments. Cells were grown on either solid or liquid YPD medium (1\% yeast extract, $2 \%$ peptone, and $2 \%$ glucose) at $30^{\circ} \mathrm{C}$. Yeast growth was monitored by optical density at $600 \mathrm{~nm}\left(\mathrm{OD}_{600}\right)$. 


\subsection{Elutriation}

Cells grown in overnight cultures were transferred to fresh media and kept growing for $24 \mathrm{~h}$. Then they were directly subjected to the elutriation system (Beckman Coulter USA, Avanti $\mathrm{J}-26 \mathrm{XPI}$ ) in order to separate the young and the old cells. Cells with 7-10 $\mu \mathrm{m}$ range were considered as the young cells and $15 \mu \mathrm{m}$ and greater were considered as the old cells.

\subsection{Formation of spheroplasts by cell wall degradation}

Pellets were suspended in ice cold $\mathrm{S}$ buffer (1 M sorbitol, $25 \mathrm{mM}$ $\mathrm{KH}_{2} \mathrm{PO}_{4}, \mathrm{pH} 6.5$ ) to a density of $1.2 \times 10^{7}$ cells $/ \mathrm{ml}$ and then centrifuged $2 \mathrm{~min}$ at $4000 \mathrm{rpm}$ at $4{ }^{\circ} \mathrm{C}$. The cells were washed twice with the same volume of ice-cold deionized water and diluted in $1 \mathrm{ml}$ ice cold S-buffer. Then cells were pelleted by centrifugation for $2 \mathrm{~min}$ at $4000 \mathrm{rpm}$ at $4{ }^{\circ} \mathrm{C}$. Pellets were resuspended in lyticase buffer $(3 \mathrm{mg} / \mathrm{ml}$ lyticase, $500 \mu \mathrm{l} 2 \times \mathrm{S}$ buffer, $300 \mu \mathrm{l}$ deionized water and $50 \mathrm{mM} \beta$-mercaptoethanol) and incubated at $37{ }^{\circ} \mathrm{C}$ in water bath for $30 \mathrm{~min}$ in order to get a good number of spheroplasts. At the end, spheroplasts were collected by centrifugation at $14,000 \mathrm{rpm}$ for $2 \mathrm{~min}$.

\subsection{Comet assay}

Many difficulties for yeast comet assay have been reported previously due to small nucleus and presence of the cell wall. We followed the procedures described by Azevedo et al. [13] with some modifications. A good number of spheroplast with degraded cell wall was obtained by applying $3 \mathrm{mg} / \mathrm{ml}$ lyticase at $37^{\circ} \mathrm{C}$ in water bath for $30 \mathrm{~min}$. We also changed the voltage and duration of electrophoresis to view the complete migration of the damaged DNA. In brief, 1.5\% Low Melting Point Agarose (LMPA) (w/v in S buffer) and $0.5 \%$ Normal Melting Agarose (NMA) (w/v in distilled water) were prepared. These were heated by microwave oven and while NMA was hot, slides were dipped up to one-third of the frosted area. Then the slides were air dried and stored at room temperature until needed. Pelleted spheroplasts were resuspended in $80 \mu \mathrm{LMA}(1.5 \%)$ at $37^{\circ} \mathrm{C}$ and quickly applied the mixure onto previously prepared $0.5 \%$ NMA coated slides and covered with cover slips. The cover-slips were then removed and the slides immersed in a freshly prepared lysis solution $(30 \mathrm{mM} \mathrm{NaOH}, 1 \mathrm{M} \mathrm{NaCl}, 0.5 \%$ w/v laurylsarcosine, $50 \mathrm{mM}$ EDTA, $10 \mathrm{mM}$ Tris-HCl, pH 10-10.5) for a minimum of at least $1 \mathrm{~h}$ and a maximum of two, at $4{ }^{\circ} \mathrm{C}$. Then the slides were placed side by side on a horizontal gel box near one end, as close together as possible. The buffer reservoirs were filled with freshly made electrophoresis buffer $(300 \mathrm{mM} \mathrm{NaOH}, 10 \mathrm{mM}$ EDTA, $\mathrm{pH}>12$ ) until the liquid level completely covered the slides. The slides were taken in the alkaline buffer for $3 \times 20$ min to allow DNA to unwind. Power supply was turn onto $20 \mathrm{~V}$ and $250 \mathrm{~mA}$ by raising or lowering the buffer level. The slides were then electrophoresed using agarose gel electrophoresis unit for $12 \mathrm{~min}$. Then the slides were coated drop wise with Neutralization Buffer: (0.4 M Tris was added to $\sim 800 \mathrm{ml} \mathrm{d}_{2} \mathrm{O}$ and $\mathrm{pH}$ was adjusted to 7.5 with concentrated ( $>10 \mathrm{M}$ ) $\mathrm{HCl}$ : q.s. to $1000 \mathrm{ml}$ with $\mathrm{dH}_{2} \mathrm{O}$ ) for at least $5 \mathrm{~min}$ and repeated twice. The samples were fixed, first with $75 \%$ and then $100 \%$ ethanol. After successive dehydration the slides were dried in the air at RT or in a laminar flow chamber. The samples were then stained by pipeting $100 \mu \mathrm{l}$ of a $10 \mu \mathrm{g} / \mathrm{ml}$ stock solution of Ethidium bromide directly onto each slide and incubated for $20 \mathrm{~min}$. The stained slides were then rinsed in $400 \mathrm{ml}$ distilled water to remove excess stain and the cover slips were placed over the slides.

\subsection{Confocal microscopy and evaluation of DNA damage}

To visualize DNA damage, comets were observed and counted under a confocal fluorescence microscope $(1000 \times)$ using $488 \mathrm{~nm}$ band-pass filter following the staining of DNA with the fluorescent dye ethidium bromide. Pictures were taken with a CCD camera (Andor technology). Three independent repetitions of the experiments were performed. In each experiment, three hundred
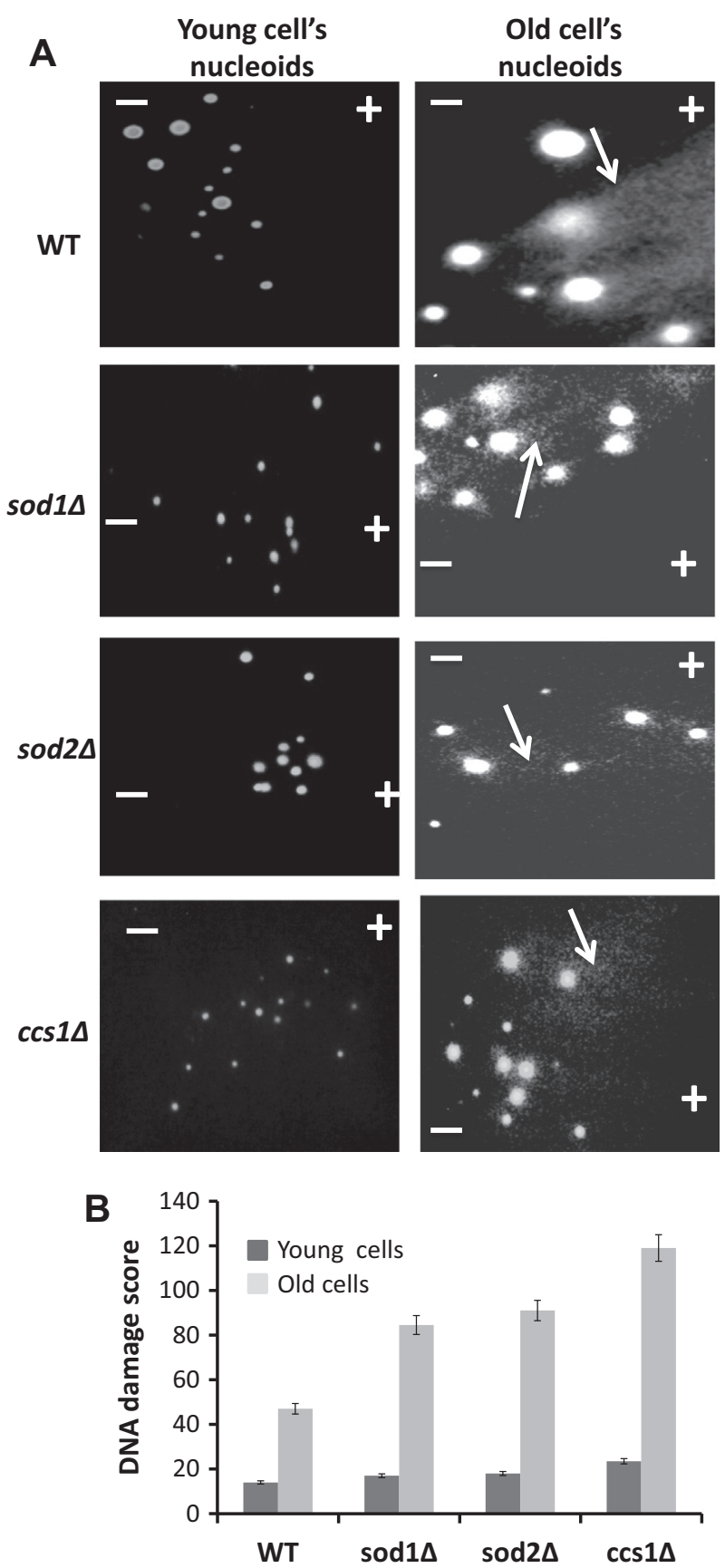

Fig. 1. Comet assay for wild type and SOD deficient cells. Cells were grown in YPD media, young and old cells were separated by an elutriation system and DNA damage rates were assessed by the yeast comet assay and tails were counted for 300 comets for each sample. (A) Confocal fluorescence microscopic analyses of comets at $1000 \times$ magnification. The symbol - and + represent cathode and anode respectively and arrows show the comet tails. (B) Evaluation and comparison of the comet frequencies based on the damage score among the young and old yeast strains (see Table 1). Error bars show standard deviation from three repetitive experiments. 
nucleoids were analyzed using visual classification based on the migration of DNA fragments of the nucleus.

\subsection{ROS measurement by flow cytometry}

Endogenous ROS levels of wild type and mutant cells $\left(\mathrm{OD}_{600}=0.2\right)$ were measured by a flow cytometer (FACS-BD) using $5 \mu \mathrm{M} 2^{\prime}, 7^{\prime}$ - DCF-DA (Invitrogen) fluorescence dye (excitation/emission $=488 / 525)$ according to manufacturer's protocol.

\subsection{Statistical analysis}

Data were presented as the frequency of damaged cells, class distribution and damage scores. Comets were grouped into four groups $(0,1,2$ and 3 ; representing no, little, medium and high damage respectively). Damage score was calculated as the sum of nucleoids in each group multiplied by the number of groups $(0-3)$. Statistical analysis was performed using the 2 tailed paired $T$ test.

\section{Results and discussion}

It has been shown that deletion of yeast SOD1, SOD2 and CCS1 genes dramatically decreases the replicative lifespan [14]. In Caenorhabditis elegans, deletion of SOD genes leads to unexpected results; absence of SOD2 gene causes an increase and simultaneous deletion of all five SOD genes causes no shortage in the lifespan [15]. It has been reported that Drosophila null mutations for either the cytoplasmic Cu/ZnSOD or the mitochondrial MnSOD greatly decreases viability and the life span [16], however in mice only SOD2 mutation has a severe effect $[17,18]$. Thus, regulation of the life span by SODs is a controversial issue in different organisms and further characterization of SOD deficient cells needs to be performed to understand the ambiguities regarding their regulatory roles in the life span.

In order to understand the mechanisms how SOD genes affect the life span in yeast, we collected young and old cells lacking SOD1, SOD2 and CSS1 genes and analyzed their genomic integrity by the whole cell comet assay. We analyzed 300 nucleoids for each sample and evaluated the results by statistical methods as described in the Section 2.

Fig. 1A shows representative pictures for comet assays for wild type and mutant strains. As seen in left panel (Fig. 1A) young nucleoids had no tails and consisted of only head regions, but, old cells (right panel) displayed nucleoidal tails (white arrows) indicating the occurrence of DNA damage in these cells.

When we analyzed young cells for their DNA damage contents, indicated as DNA damage scores in Fig. $1 \mathrm{~B}$ and Table 1, we did not observe any significant differences among the wild type, sod $1 \Delta$ and $\operatorname{sod} 2 \Delta$ mutants $(p>0.05)$. However, young $\operatorname{ccs} 1 \Delta$ cells showed a
64\% higher DNA damage score compared to that of the wild type cells indicating that, absence of CCS1 gene creates more profound phenotype than in the absence of either SOD1 or SOD2 genes. Using mitochondrial protein carbonylation levels as a measure of oxidative protection, O'Brien et al. (2004) showed that logarithmically growing $\operatorname{sod} 1 \Delta$ and $\operatorname{sod} 2 \Delta$ cells have similar protein carbonylation levels to that of the wild type cell [19]. We could consider logarithmically growing cells as young cells, since $97 \%$ of the cells in a given population is made of cells divided 4 times or less. Thus, their results also suggest that the absence of SOD1 and SOD2 does not make young cells vulnerable to oxidative damage.

Replicatively old cells harbored substantial amount of DNA damages (Fig. 1B, grey bars) when compared to their young counterparts (dark bars) $(p<0.05)$. Aging process caused more than 3fold higher level of DNA damage in the wild type, and approximately 5 -fold higher level of DNA damage in $\operatorname{sod} 1 \Delta, \operatorname{sod} 2 \Delta$ and ccs $1 \Delta$ mutants.

In order to test the idea that absence of SOD genes leads to ROS accumulation which damages DNA and ultimately causes aging, we analyzed the ROS levels of the young and the old cells by a flow cytometric approach after staining the cells with fluorescein (FITC) (Fig. 2). Interestingly, deletion of the SOD genes or CCS1 resulted in approximately $20 \%$ higher level of ROS accumulation in young cells when compared to that of the wild type (Fig. 2B, left panel). Nevertheless, young cells did not contain oxidative DNA damages that could be detected by the comet assay (Fig. 1A). However, old cells harbored significantly higher amount of ROS, and the extend of this increase was $67 \%$ for $\operatorname{sod} 1 \Delta, 88 \%$ for $\operatorname{sod} 2 \Delta$, and $92 \%$ for $\operatorname{ccs} 1 \Delta$ cells. The higher level of ROS was consistent with the higher level of DNA damage in old cells.

Our analyses showed that the $\operatorname{css} 1 \Delta$ mutants harbor the highest amount of ROS and DNA damage among the mutants. Ccs1 is known as the sole cupper provider for Sod1p in yeast [20], but absence of CCS1 gene clearly generates more damaging conditions than absence of SOD1. Consistent with this observation, $\operatorname{ccs} 1 \Delta \mathrm{mu}-$ tants were previously shown to have more oxidative damages than $\operatorname{sod} 1 \Delta$ and $\operatorname{sod} 2 \Delta$ mutants [21]. It is not clear why $\operatorname{ccs} 1 \Delta$ cells are more vulnerable to oxidative damage. It could be possible that Ccs1 has other functions or interactions apart from being copper chaperone for Sod1 and thus deletion of CCS1 may cause a pleotropic effect on the life span and ROS accumulation.

Our analyses suggest that SOD function is dismissible in young stage and support the idea that SODs are required for antioxidant protection during the aging process. Moreover, short lifespan of superoxide dismutase mutants in yeast and occurrence of extensive DNA damages during the aging process in these cells support the idea that oxidative stress is a modulator of the life span. Increased ROS production results in an increased rate of DNA damage and mutagenesis, thus causing a vicious cycle of increasing oxidative damage which eventually culminates in aging and death.

Table 1

Analyses of comet assay results.

\begin{tabular}{|c|c|c|c|c|c|c|c|c|}
\hline \multirow[t]{2}{*}{ Cells } & \multirow[t]{2}{*}{ Ages } & \multirow[t]{2}{*}{ Nucleoids analysed } & \multirow[t]{2}{*}{ Comets (\%) } & \multicolumn{4}{|l|}{ Comet classes } & \multirow[t]{2}{*}{ DNA damage score } \\
\hline & & & & 0 (no damage) & 1 (little) & 2 (Med) & 3 (High) & \\
\hline \multirow[t]{2}{*}{ WT } & Young & 300 & $7.0 \pm 1.5$ & $93.0 \pm 1.5$ & $2.5 \pm 0.7$ & $2.0 \pm 0$ & $2.5 \pm 0.7$ & $14 \pm 2.5$ \\
\hline & Old & 300 & $23.5 \pm 0.7$ & $76.5 \pm 0.7$ & $9.0 \pm 4.2$ & $5.5 \pm 2.1$ & $9 \pm 2.8$ & $47 \pm 9.8$ \\
\hline \multirow[t]{2}{*}{$\operatorname{sod} 14$} & Young & 300 & $9.0 \pm 0$ & $91.0 \pm 0$ & $3.5 \pm 0.7$ & $3.0 \pm 1.4$ & $2.5 \pm 0.2$ & $17 \pm 2.0$ \\
\hline & Old & 300 & $44.5 \pm 1.4$ & $55.5 \pm 1.4$ & $19 \pm 1.4$ & $11 \pm 1.4$ & $14.5 \pm 0.7$ & $84.5 \pm 13.3$ \\
\hline \multirow[t]{2}{*}{$\operatorname{sod} 2 \Delta$} & Young & 300 & $11.5 \pm 0.7$ & $88.5 \pm 0.7$ & $5.0 \pm 0$ & $4.0 \pm 0$ & $2.5 \pm 0.7$ & $18.0 \pm 1.7$ \\
\hline & Old & 300 & $48.5 \pm 2.0$ & $51.5 \pm 2.0$ & $25.5 \pm 2.1$ & $9.5 \pm 0.7$ & $15.5 \pm 2.1$ & $91 \pm 14.3$ \\
\hline \multirow[t]{2}{*}{$\operatorname{ccs} 1 \Delta$} & Young & 300 & $13.0 \pm 1.5$ & $87.0 \pm 1.5$ & $5.5 \pm 0.7$ & $4.5 \pm 0.7$ & $3 \pm 0$ & $23.5 \pm 2.0$ \\
\hline & Old & 300 & $60.5 \pm 0.7$ & $39.5 \pm 0.7$ & $21 \pm 1.4$ & $20.5 \pm 3.5$ & $19 \pm 1.4$ & $119 \pm 18.0$ \\
\hline
\end{tabular}


A

Young Cells
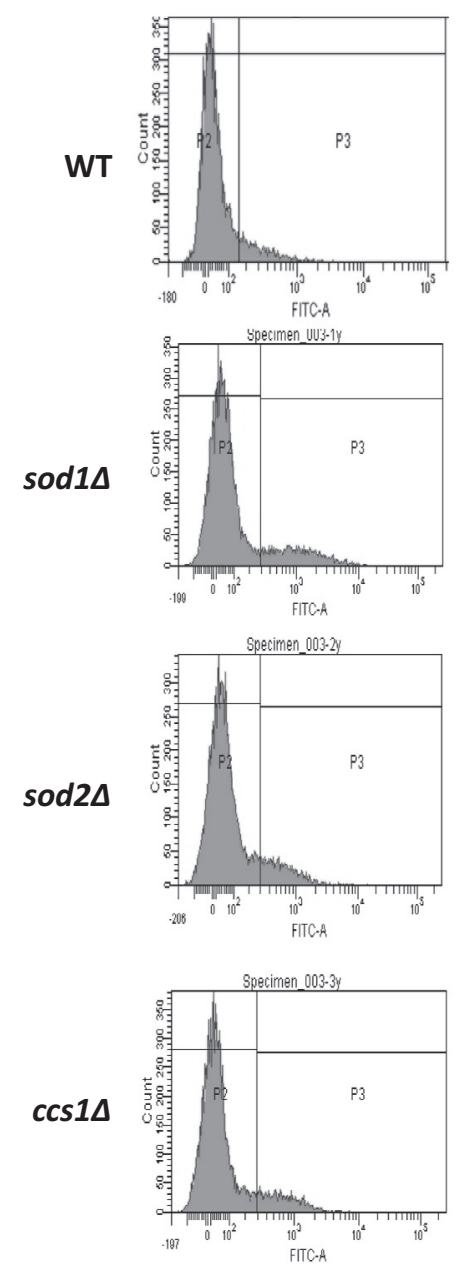

Old cells
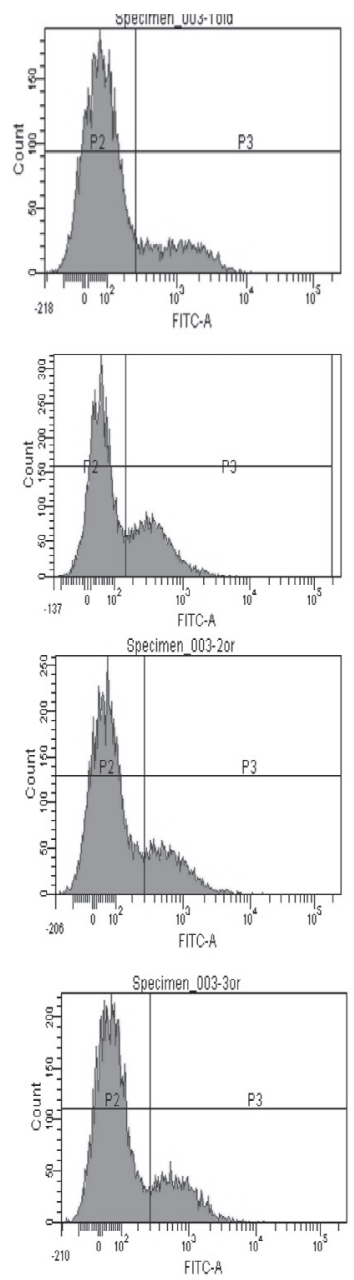

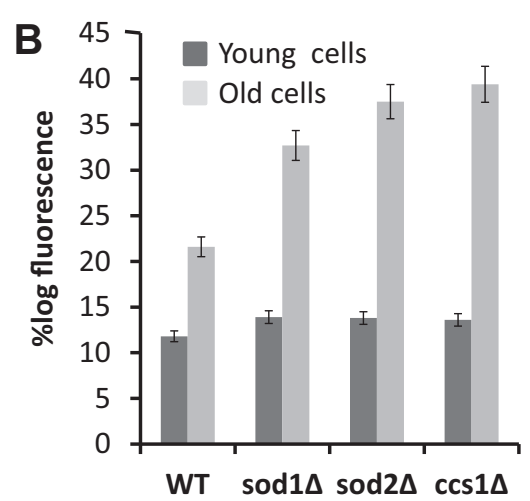

Fig. 2. Flow cytometric analyses of cellular ROS contents. (A) Representative histograms showing the endogenous ROS in young and old stages of cells using $2^{\prime}, 7^{\prime}$-DCF-DA $(5 \mu \mathrm{M})$ fluorescent dye (excitation/emission $=488 / 525$ ) by a flow cytometer (FACS-BD). (B) Relative levels of endogenous ROS detected by flow cytometer. Error bars show the standard deviations of three repetitive experiments. Y stands for young cells and $\mathrm{O}$ stands for old cells.

\section{Acknowledgment}

The authors are thankful to Dr. Alper Arslanoglu, Dr. Serdar Ozcelik and Biological Mass Spectrometry (Izmir Institute of
Technology) facilities for their instrumental help. This work was supported by grant 2008K120730 from the State Planning Organization of Turkey. K.A. Muid was supported by a pre-doctoral fellowship from the Scientific and Technological Research Council of Turkey (TUBITAK-BIDEP).

\section{References}

[1] B.S. Mandavilli, J.H. Santos, B. Van Houten, Mitochondrial DNA repair and aging, Mutat. Res. 509 (2002) 127-151.

[2] E.J. Lesnefsky, C.L. Hoppel, Ischemia-reperfusion injury in the aged heart: role of mitochondria, Arch. Biochem. Biophys. 420 (2003) 287-297.

[3] D.G. Nicholls, Mitochondrial function and dysfunction in the cell: its relevance to aging and aging-related disease, Int. J. Biochem. Cell Biol. 34 (2002) 13721381.

[4] A. Grzelak, E. Macierzynska, G. Bartosz, Accumulation of oxidative damage during replicative aging of the yeast Saccharomyces cerevisiae, Exp. Gerontol. 41 (2006) 813-818.

[5] S. Boiteux, M. Guillet, Abasic sites in DNA: repair and biological consequences in Saccharomyces cerevisiae, DNA Repair (Amst) 3 (2004) 1-12.

[6] M.F. Alexeyev, S.P. Ledoux, G.L. Wilson, Mitochondrial DNA and aging, Clin. Sci. 107 (2004) 355-364.

[7] C.G. Silva, R.S. Herdeiro, C.J. Mathias, A.D. Panek, C.S. Silveira, V.P. Rodrigues, M.N. Renno, D.Q. Falcao, D.M. Cerqueira, A.B. Minto, F.L. Nogueira, C.H. Quaresma, J.F. Silva, F.S. Menezes, E.C. Eleutherio, Evaluation of antioxidant activity of Brazilian plants, Pharmacol. Res. 52 (2005) 229-233.

[8] I. Fridovich, Superoxide radical and superoxide dismutases, Annu. Rev. Biochem. 64 (1995) 97-112.

[9] L.A. Sturtz, K. Diekert, L.T. Jensen, R. Lill, V.C. Culotta, A fraction of yeast Cu, Znsuperoxide dismutase and its metallochaperone, CCS, localize to the intermembrane space of mitochondria. A physiological role for SOD1 in guarding against mitochondrial oxidative damage, J. Biol. Chem. 276 (2001) 38084-38089.

[10] E. Luk, L.T. Jensen, V.C. Culotta, The many highways for intracellular trafficking of metals, J. Biol. Inorg. Chem. 8 (2003) 803-809.

[11] R.L. Casareno, D. Waggoner, J.D. Gitlin, The copper chaperone CCS directly interacts with copper/zinc superoxide dismutase, J. Biol. Chem. 273 (1998) 23625-23628.

[12] P.J. Schmidt, M. Ramos-Gomez, V.C. Culotta, A gain of superoxide dismutase (SOD) activity obtained with CCS, the copper metallochaperone for SOD1, J. Biol. Chem. 274 (1999) 36952-36956.

[13] F. Azevedo, F. Marques, H. Fokt, R. Oliveira, B. Johansson, Measuring oxidative DNA damage and DNA repair using the yeast comet assay, Yeast 28 (2011) 5561.

[14] E.S. Unlu, A. Koc, Effects of deleting mitochondrial antioxidant genes on life span, Ann. N. Y. Acad. Sci. 1100 (2007) 505-509.

[15] S.K. Kim, J.M. Van Raamsdonk, S. Hekimi, Deletion of the mitochondrial superoxide dismutase sod-2 extends lifespan in Caenorhabditis elegans, PLoS Genet. 5 (2009) e1000361.

[16] W. Hr, Superoxide dismutase, aging and degenerative disease, Free Radic. Biol. Med. 17 (1994) 249-258.

[17] D. Hinerfeld, M.D. Traini, R.P. Weinberger, B. Cochran, S.R. Doctrow, J. Harry, S. Melov, Endogenous mitochondrial oxidative stress: neurodegeneration, proteomic analysis, specific respiratory chain defects, and efficacious antioxidant therapy in superoxide dismutase 2 null mice, J. Neurochem. 88 (2004) 657-667.

[18] T.T. Huang, E.J. Carlson, A.M. Gillespie, Y. Shi, C.J. Epstein, Ubiquitous overexpression of CuZn superoxide dismutase does not extend life span in mice, J. Gerontol.: Biol. Sci. 55A (2000) B5-B9.

[19] R.D. Kristin, M. O'Brien, Marcella Engle, Robert O. Poyton, Mitochondrial protein oxidation in yeast mutants lacking manganese-(MnSOD) or copperand zinc-containing superoxide dismutase (CuZnSOD), J. Biol. Chem. 279 (2004) 51817-51827.

[20] J.M. Leitch, L.T. Jensen, S.D. Bouldin, C.E. Outten, P.J. Hart, V.C. Culotta, Activation of $\mathrm{Cu}$, oxygen and the copper chaperone CCS, J. Biol. Chem. 284 (2009) 21863-21871.

[21] A.B. Demir, A. Koc, Assessment of chronological lifespan dependent molecular damages in yeast lacking mitochondrial antioxidant genes, Biochem. Biophys. Res. Commun. 400 (2010) 106-110. 